\title{
Do country-level financial structures explain bank-level CDS
}

\section{spreads?}

\author{
Nadia Benbouzid ${ }^{\text {a }}$, Sushanta K. Mallick ${ }^{\mathrm{b}, *}$, Ricardo M. Sousa ${ }^{\mathrm{c}, \mathrm{d}}$ \\ a University of Greenwich, School of Business, Old Royal Naval College, 30 Park Row, London SE10 9LS, United Kingdom \\ ${ }^{\mathrm{b}}$ Queen Mary University of London, School of Business and Management, Mile End Road, London E1 4NS, United Kingdom \\ ${ }^{\mathrm{c}}$ University of Minho, Department of Economics and Economic Policies Research Unit (NIPE), Campus of Gualtar, $4710-057$ Braga, Portugal \\ ${ }^{\mathrm{d}}$ London School of Economics and Political Science, LSE Alumni Association, Houghton Street, London WC2A 2AE, United Kingdom
}

Keywords:

Bank CDS spreads

Financial structures

Bank characteristics

\begin{abstract}
A B S T R A C T
The existing literature has typically focused on bank-level characteristics to uncover the main drivers of bank CDS spreads. In this paper, we use data for 58 banks from 15 countries over the period 2004-2011 to assess whether country-level factors also explain variations in bank CDS spreads. In particular, we focus on financial structure indicators (namely, financial stability, depth, access and efficiency) and country risks (i.e. economic, financial and political rating risks) to explain why some banks experience higher levels of credit risk relative to others across countries. We find that while country-level financial instability is associated with higher credit risk; bank-level profitability, liquidity and improved asset quality are linked with lower credit risk. In addition, although country-level financial depth (as an indicator of credit bubble) contributes to higher CDS spreads, house price appreciation tends to dampen credit risk.
\end{abstract}

\section{Introduction}

The perception of credit risk in the banking sector has deeply changed since the beginning of the 2008-2009 crisis when the financial system was hit by a wave of defaults, with the Credit Default Swaps (CDS) spreads reaching record high levels in most financial markets. One of the amplification mechanisms of the sub-prime mortgage market crisis was the transfer of credit risk within the financial system either via CDS trades or CDOs (Collateralized debt obligations) issuances. Thus, CDS spreads have been identified as a superior measure of credit risk compared to bond spreads (Hull et al., 2004; Blanco et al., 2005; Houweling and Vorst, 2005; Zhu, 2006).

The past literature on CDS spreads and their determinants can be split into two main streams. The first one has mainly focused on macroeconomic drivers, including interest rates, yield spreads and inflation (Duffie and Singleton, 1999; Lekkos and Milas, 2001; In et al., 2003; Alexander and Kaeck, 2008; Naifar, 2010). The second has looked at bank-level

\footnotetext{
The authors also would like to thank the editor and the two anonymous reviewers of this journal for their very constructive comments. We are solely responsible for any error that might yet remain. Sousa acknowledges that this work has been financed by Operational Programme for Competitiveness Factors - COMPETE and by National Funds through the FCT - Portuguese Foundation for Science and Technology within the remit of the project "FCOMP-010124-FEDER-037268 (PEst-C/EGE/UI3182/2013)."

* Corresponding author.

E-mail addresses: n.benbouzid@gre.ac.uk (N. Benbouzid), s.k.mallick@qmul.ac.uk (S.K. Mallick), rjsousa@eeg.uminho.pt, rjsousa@alumni.lse.ac.uk (R.M. Sousa).
} 
characteristics, such as asset quality, credit ratings, leverage, liquidity and volatility (Collin-Dufresne et al., 2001; Campbell and Taksler, 2003; Benkert, 2004; Hull et al., 2004; Fabozzi et al., 2007; Chiaramonte and Casu, 2013).

Yet, little effort has been made to combine both sets of factors in a unified framework. More importantly, while CDS spreads can differ across countries as a reflexion of their heterogeneous financial structures (such as, financial soundness (i.e. financial stability) and financial market development (i.e. financial depth)), the relationship between the former and the latter has not been fully explored.

A few exceptions include the works of Myers and Rajan (1998) and Diamond and Rajan (2000), who show that the minimum regulatory capital that banks need to hold depends primarily on their capital buffers, and these tend to be adjusted in accordance with changes in banks' equity prices and stockholders' and debt holders' preferences. Similarly, only a handful number of research pieces have highlighted the systemic nature of the CDS market given its size (ISDA, 2008), and, thus its relationship with financial (in)stability (Huang et al., 2009; Markose et al., 2012; Rodríguez-Moreno and Peña, 2013). These are the main gaps in the empirical literature that we try to fill in the current work. Using a unique dataset covering bank CDS spreads in 58 banks from 15 countries over the period 2004-2011, we investigate if differences in country-level financial structures and bank-level characteristics translate into variation in credit risk across banks.

Given the role played by the sub-prime mortgage sector in the emergence of the global financial crisis, we account for the dynamics of housing prices. We also look at bank-level drivers of credit risk and control for economic, financial market and political risk ratings. Finally, we consider major indicators of the financial structure of the country that can affect bank CDS spreads, namely: (i) financial stability; (ii) financial depth; (iii) financial access; and (iv) financial efficiency.

Our main findings are twofold. First, country-level financial stability is negatively associated with credit risk. Thus, more stable financial structures help reduce bank CDS spreads. Second, bank-level profitability and asset quality are positively linked with bank CDS spreads. Therefore, a rise in bank-level profitability (operating income) or higher liquidity or an improvement in the quality of assets held by banks seems to be reflected in lower credit risk. Although country-level financial depth (as an indicator of credit bubble) contributes to higher CDS spreads, house price appreciation tends to dampen credit risk.

The rest of this paper is organized as follows. Section 2 discusses the literature review. Section 3 describes the data and presents the econometric methodology. In Section 4, we report the empirical results. Finally, Section 5 concludes.

\section{Literature review}

In this section, we look at the existing literature on two main sets of determinants of bank CDS spreads: (1) bank-level characteristics; and (2) country-level factors. Among bank-level characteristics, we focus on: (i) the asset quality; (ii) the profitability; (iii) the liquidity ratio; (iv) the regulatory capital; and (v) the leverage ratio. As for the major country-level drivers of bank CDS spreads, we can mention: (i) financial stability; (ii) financial depth; (iii) financial access; and (iv) financial efficiency.

\subsection{Bank-level determinants}

\subsubsection{Asset quality}

Asset quality has typically been incorporated as a driver of credit risk in CAMEL indicators approaches. Ötker-Robe and Podpiera (2010) look at fundamental determinants of credit default risk for large and complex EU financial institutions, and show that asset quality does not make a substantial difference for pricing of CDS instruments. The authors justify the lack of statistical significance to the period of analysis which only covered until the beginning of the recent crisis. Chiaramonte and Casu (2013) highlight that in the pre-crisis period, financial markets were not concerned with the low quality of bank assets.

Asset quality can also be reflected in credit ratings of the underlying asset on which CDS contracts are written. For instance, several authors identify credit ratings as an important driver of credit risk (Hull et al., 2004; Fabozzi et al., 2007). With the bursting of the housing bubble and the beginning of the financial crisis, most securitized instruments on which CDS contracts were written defaulted, leading to a rise in credit risk (Benbouzid and Mallick, 2013).

\subsubsection{Profitability}

Ötker-Robe and Podpiera (2010) analyse 29 EU large financial institutions over the period 2004-2009, and find that riskier business activities raise CDS spreads and are associated with lower returns on assets (ROA). Chiaramonte and Casu (2013) use pre-crisis, crisis and post-crisis data to show that a high return on equity (ROE) increases the probability of default.

\subsubsection{Liquidity ratio}

The issue of bank illiquidity was greatly debated among regulators in the aftermath of the Great Recession. From a theoretical point of view, Diamond and Rajan (2005) argue that banks can go bankrupt either because they become insolvent or because they suffer from an aggregate shortage of liquidity, which in turn makes them insolvent. Campbell and Taksler (2003) also consider aggregate liquidity when modelling credit spreads.

From an empirical perspective, Tang and Yan (2007) find that liquidity and liquidity risk account for, approximately, 20\% of CDS spreads fluctuations. While some researchers argue that CDS spreads only reflect credit risk (Blanco et al., 2005; 
Longstaff et al., 2005), others argue that liquidity risk is more important in explaining CDS spreads than firm-level credit risk (Corò et al., 2013).

\subsubsection{Regulatory capital}

The recent financial crisis brought into light the importance of an adequate regulatory structure and a sound supervisory regime under which banks operate, which may also eventually require stricter capital requirements and both micro- and macro-prudential elements (Rossignolo et al., 2013). Previous studies questioned whether banks were well capitalized before and after the financial crisis. For instance, Ambrose et al. (2005) argue that the level of capital held by banks that trade securitized derivatives was too high.

In contrast, Roesch and Scheule (2012) find that, before 2007, the level of regulatory capital held by U.S. banks that conduct securitization was insufficient to cover all underlying risks associated with structured derivative trading. This result is in accordance with the empirical evidence from Kretzschmar et al. (2010), who also view banks as undercapitalized before the financial crisis. And Tian et al. (2013) show that high levels of minimum regulatory capital did not necessarily imply that banks could avoid contagion.

\subsubsection{Leverage ratio}

Before the global financial turmoil, banks had excessive leverage exposure as they were granting loans to low-income consumers. In the wake of the summer of 2007, several investors defaulted on their obligations, prompting a dramatic increase in CDS spreads.

Leverage indeed appears to be an important driver of CDS spreads and credit risk (Ericsson et al., 2009; Annaert et al., 2013; Galil et al., 2014). The empirical evidence suggests that leverage is positively associated with credit spreads (CollinDufresne et al., 2001; Alexander and Kaeck, 2008).

\subsection{Country-level determinants}

\subsubsection{Financial stability}

Over the period 2001-2008, the CDS market generated, approximately, \$60 trillion (ISDA, 2008). And with the beginning of the financial crisis of 2008-2009, many countries registered extremely high levels of CDS spreads, which brought to light the danger of defaults, domino effects and contagion among countries (Cont, 2010).

Not surprisingly, the large size of the CDS market raised concerns about the relationship of this sector with the stability of the overall financial system. Indeed, the dimension of the CDS market is pointed out as impeding the internalization of potential failures from deeply connected financial institutions (Markose et al., 2012). Nijskens and Wagner (2011) also argue that although banks that conduct credit risk transfer may appear to be less risky when considered individually, they pose a great risk to financial stability when treated jointly.

In this context, some studies suggest that CDS spreads are a good proxy for systemic stability. For instance, RodríguezMoreno and Peña (2013) show that the best measure of systemic risk is the first principal-component of a portfolio of CDS spreads. Similarly, Chan-Lau and Gravelle (2005) and Huang et al. (2009) use CDS spreads and equity prices to derive an indicator of systemic risk and to compute default probabilities.

\subsubsection{Financial depth}

The period of early 2000s was marked by an economic boom with easy access to credit, high mortgage lending and excessive foreign funding inflows. Furthermore, capital markets were also an important source of financing for banks. Among the factors that paved the way for such developments, the literature has typically considered low interest rates, financial innovation and financial imbalances (Bernanke and Gertler, 1999; Taylor, 2009; Obstfeld, 2010). Credit growth was elevated when interest rates were depressed (Jordà et al., 2011) and propelled a pronounced house price appreciation (Milcheva, 2013).

\subsubsection{Financial access}

The extent to which financial systems channel savings to economic agents that have the best ability to maximise investment opportunities is of crucial importance. Moreover, better access to financial institutions also helps to ensure borrowers' credit worthiness, which minimises the risk of default and the overall credit risk. Yet, in the wake of the Great Recession, frozen capital markets reduced investors' and firms' ability to access financial services.

The existing literature reveals that there is a positive link between economic growth and the degree of development of the financial system, and the latter can be accessed (among others) by the degree of financial access and outreach to banks (Levine, 2005). Moreover, while state-owned firms appear to have lowered outreach (Beck et al., 2007), privately-owned and foreign financial institutions offer more flexibility to depositors, which improves outreach (Beck et al., 2008).

\subsubsection{Financial efficiency}

In a study conducted by Hasan et al. (2014), the authors use a sample of 161 global banks headquartered in 23 countries to investigate the key factors that affect pricing of global bank credit risk. They show that CAMEL indicators (capital, asset quality, management quality, earnings potential and liquidity) display a significant explanatory power for bank CDS price 
fluctuations. Kick and Koetter (2007) and Poghosyan and Cihak (2009) highlight that banks with better capitalization are more likely to have greater earnings, while banks under stress have lower earnings.

\section{Data and econometric methodology}

\subsection{Data}

We use a panel of 58 banks from 15 countries over the period 2004-2011, for which bank CDS data are available. ${ }^{1}$

Bank CDS spreads are obtained from Thomson Reuters Datastream, published by the Credit Market Analysis (CMA) Group. We focus on the 5-Year Credit Default Swap (CDS) Index as a proxy for credit risk, as this is widely accepted as the most liquid type of CDS index. CDS spreads are expressed in basis points as 'CDS Premium Mid', which corresponds to the average of 'CDS premium bid' and 'CDS premium offered'. Thus, the CDS spread reflects the mid-rate spread between the entity and the relevant benchmark curve.

In the light of the fact that the Great Recession had its roots in the sub-prime mortgage crisis, we consider the house price index among the key determinants of bank CDS spreads. We use a log transformation and the data are denominated in local currency and expressed in basis points. The main source is the Thomson Reuters Datastream database. Given the high reliance of advanced countries on mortgage-backed securitization, changes in the real estate sector are likely to affect bank CDS spreads.

Among the bank-level characteristics, the main source of the data is the Bankscope, published by the Bureau Van Dijk and we include the following variables in the analysis:

- Leverage: it is defined as the ratio of long-term debt to common equity. It is denominated in local currency.

- Regulatory capital: i.e. the Tier 2 capital, which is computed as the difference between total capital and Tier 1 capital.

- Asset quality: it is the ratio of impaired loans to equity.

- Liquidity: the ratio of liquid assets to total deposits and borrowings.

- Operations income: it is defined as the ratio of earnings before interest, taxes, and amortization (EBITA) to average assets an indicator of profitability.

As for the country-level factors, we consider rating risk indices. These are economic, financial and political risk rating indices. High economic, financial and political risk is associated with environments of heightened uncertainty, thus, impinging negatively on credit risk. The source of the data is the International Country Risk Guide (ICRG).

Finally, as indicators of the financial structure, we look at four variables measured at the aggregate level, namely:

- Financial stability: this is captured by the bank Z-score, which is also referred to as the distance to default. A more stable financial system would have a higher bank Z-score, thus, a lower probability of going insolvent and a lower CDS spread. The bank Z-score is measured as the ratio of defaulting loans (i.e. payments of interest and principal past due by 90 days or more) to total gross loans (i.e. the total value of the loan portfolio). ${ }^{2}$ The amount of nonperforming loans includes the gross value of loans (as recorded on the balance sheet), not just the amount that is overdue. The data are retrieved from the Global Financial Development Database (GFDD) of the World Bank (available at: http://go.worldbank.org/AWACYAMMM0). Raw data come from Bankscope.

- Financial depth: this is proxied by total assets held by deposit money banks as a share of GDP. The higher this ratio is, the better banks' ability to generate credit will be. This can lead to a rise in credit risk if credit expansion is too fast (generating bubbles) or directed to low-income consumers. In the definition of financial depth, assets include claims on domestic real non-financial sector (i.e. central, state and local governments, non-financial public enterprises and private sector). Deposit money banks comprise commercial banks and other financial institutions that accept transferable deposits, such as demand deposits. The data was retrieved from the World Bank's GFDD Database. Raw data come from the International Financial Statistics (IFS) of the International Monetary Fund (IMF) and World Bank GDP estimates. ${ }^{3}$

- Financial access: this variable is proxied by the number of commercial bank branches per 100,000 adults. It reflects the extent to which investors (and, more generally, the public) can have access to bank services. A financial system that functions in an efficient way would enhance and ensure that investors have easy access to financial institutions. The data are sourced from the commercial banks' survey published by IMF and the Financial Access Survey. For each country, it is calculated as: (number of institutions + number of branches) $* 100,000 /$ adult population. The data was retrieved from the GFDD Database of the World Bank.

\footnotetext{
1 The countries included in the analysis are: Belgium, China, France, Germany, Greece, India, Ireland, Italy, Malaysia, Netherlands, Portugal, Russia, Spain, U.K. and U.S.

2 As an alternative measure of financial stability, we look at the volatility of stock price index, i.e. the 360-day standard deviation of the return on the national stock market index. The source of the raw data is from Bloomberg. For brevity, the results are not reported in the paper, but are available upon request.

${ }^{3}$ We also consider financial system deposits as a share of GDP as an alternative measure of financial deepening. It represents demand, time and saving deposits in deposit money banks and other financial institutions. We do not present this evidence in the paper, but it is available upon request.
} 
- Financial efficiency: it corresponds to the ratio of overhead costs (i.e. operating costs) to total assets, which is computed using bank-by-bank unconsolidated data. When banks have high returns, this will typically attract more investors, as the banking sector can enhance its marketability and position itself as strong and healthy. High net interest rate margins tend to be associated with a low default probability and a narrow bank CDS spread. In the definition of profitability, total assets include total earning assets, cash and due from banks, foreclosed real estate, fixed assets, goodwill, other intangibles, current tax assets, deferred tax assets, discontinued operations and other assets. The country-level data are retrieved from the GFDD Database of World Bank, and raw data come from the Bankscope. ${ }^{4}$

\subsection{Econometric methodology}

Our model to assess the relevance of bank-level characteristics and country-level factors in explaining bank CDS spreads consists of the following equation:

$$
\text { BankCDS }_{i j t}=B_{0}+\theta_{i}+\psi_{t}+B_{1} \text { HousePrice }_{j t}+\boldsymbol{B}_{2} \text { Bank }_{i j t}+\text { B }_{3} \text { Country }_{j t}+\boldsymbol{B}_{4} \text { FinStruc }_{j t}+\varepsilon_{i j t}
$$

where BankCDS $S_{i t t}$ denotes the CDS spread of bank $i$ in country $j$ at time $t$, HousePrice is the house price index, Bank is a vector of bank-level characteristics (i.e. leverage, regulatory capital, asset quality, liquidity and operations income), Country is a vector of country-level factors (namely, the economic, financial and political rating risk indices), FinStruc is the vector of four financial structure indicators (i.e. financial stability, depth, access and efficiency), $\theta_{i}$ denotes bank fixed-effects and $\psi_{t}$ refers to time fixed-effects, and $\varepsilon_{i j t}$ is the error term.

We start by estimating Eq. (1) by Pooled Ordinary Least Squares (OLS). Next, we control for unobserved heterogeneity at the bank-level, by using Random Effects (RE) and Fixed-Effects (FE) estimators. We run the Hausman's (1978) specification test to assess the appropriateness of the FE estimator vis-à-vis the RE estimator. Finally, in light of the potential endogeneity, we consider a dynamic panel data framework, where we add lagged CDS spreads to the set of control variables and estimate the model using the Generalized Method of Moments (GMM) approach. Given that the number of banks ( $N$ ) (i.e. 58 banks) is larger than the number of the years $(T)$ (i.e. 7 years) in the sample, this is an appropriate estimation technique (Kiviet, 1995; Judson and Owen, 1999). As is standard in the literature, we consider the lags of the explanatory variables as instruments.

\section{Empirical results}

\subsection{Narrow version of the model}

We start by reporting the results associated with the estimation of a narrow version of Eq. (1), which includes the house price index, bank-level characteristics and country-level factors among the set of control variables, but does not take into account the key indicators of the financial structure of the country.

Tables 1-3 present a summary of the findings using the pooled OLS, the random-effects (RE) and the fixed-effects (FE) estimators, respectively. The Hausman's (1978) specification test almost unequivocally corroborates the superiority of the FE specification, as shown in Table 3.

Starting with the house price index, it can be seen that the house price is negatively related with bank CDS spreads. This result is in line with the empirical observation that, before the global financial turmoil, house prices were continuously appreciating and credit risk was low. However, when the housing bubble burst, the number of defaults increased, thus, pushing up bank CDS spreads (Benbouzid and Mallick, 2013).

In what concerns bank-level characteristics, the empirical results show that asset quality (as proxied by the ratio of impaired loans to equity) is strongly and positively correlated with bank CDS spreads. Thus, an improvement in the quality of assets held by banks is associated with a lower credit risk. In this context, our finding is consistent with the work of Chiaramonte and Casu (2013), who also highlight the importance of asset quality as a key driver of bank CDS spreads. It is also in line with the research by Ötker-Robe and Podpiera (2010), who reach the same conclusion while analyzing CDS spreads of large and complex financial institutions in the EU.

A rise in banks' profitability (as captured by the operations income ratio) is also linked with a significant reduction of bank CDS spreads. Thus, more profitable banks appear to display lower credit risk than less profitable banks.

In addition, an increase in the liquidity ratio (as expressed by the ratio of liquid assets to total deposits and borrowings) is associated with a fall in bank CDS spreads. Consequently, high liquidity levels seem to endorse banks' ability to withstand financial crises. As is well-known, in general, higher liquidity ratios reduce the risk of bank runs and allow financial institutions to meet depositors' demand for cash. Similar findings are obtained by Chen et al. (2007), Fabozzi et al. (2007), Annaert et al. (2013) and Chiaramonte and Casu (2013).

As for the leverage ratio, we uncover a positive and significant link with bank CDS spreads. Therefore, as in previous studies, higher leverage seems to be associated with higher credit risk (Collin-Dufresne et al., 2001; Alexander and Kaeck, 2008).

\footnotetext{
${ }^{4}$ Alternatively, we use returns on equity (i.e. the ratio of commercial banks' net income to yearly averaged equity) as a measure of profitability. Again, even though we do not show the results associated with this variable, they are available upon request.
} 
Table 1

Determinants of the bank CDS spreads - OLS.

\begin{tabular}{|c|c|c|c|c|c|c|c|}
\hline Variables & $(1)$ & $(2)$ & (3) & $(4)$ & $(5)$ & (6) & (7) \\
\hline House price & $\begin{array}{l}-0.0060 \\
{[0.048]}\end{array}$ & $\begin{array}{l}-0.1454^{* *} \\
{[0.062]}\end{array}$ & $\begin{array}{l}-0.1537^{* *} \\
{[0.063]}\end{array}$ & $\begin{array}{l}-0.1797^{* * * *} \\
{[0.065]}\end{array}$ & $\begin{array}{l}-0.1990^{* * *} \\
{[0.069]}\end{array}$ & $\begin{array}{l}-0.1799^{* *} \\
{[0.084]}\end{array}$ & $\begin{array}{l}-0.1773^{* *} \\
{[0.086]}\end{array}$ \\
\hline Asset quality & & $\begin{array}{l}0.0043^{* * *} \\
{[0.001]}\end{array}$ & $\begin{array}{l}0.0046^{* * * *} \\
{[0.001]}\end{array}$ & $\begin{array}{l}0.0042^{* * *} \\
{[0.001]}\end{array}$ & $\begin{array}{l}0.0040^{* * * *} \\
{[0.001]}\end{array}$ & $\begin{array}{l}0.0065^{* * *} \\
{[0.002]}\end{array}$ & $\begin{array}{l}0.0065^{* * *} \\
{[0.002]}\end{array}$ \\
\hline Operations income ratio & & & $\begin{array}{l}0.0262 \\
{[0.039]}\end{array}$ & $\begin{array}{l}0.0335 \\
{[0.039]}\end{array}$ & $\begin{array}{l}0.0229 \\
{[0.040]}\end{array}$ & $\begin{array}{l}0.0653 \\
{[0.059]}\end{array}$ & $\begin{array}{l}0.0243 \\
{[0.062]}\end{array}$ \\
\hline Liquidity ratio & & & & $\begin{array}{l}-0.0102^{* * *} \\
{[0.003]}\end{array}$ & $\begin{array}{l}-0.0100^{* * *} \\
{[0.003]}\end{array}$ & $\begin{array}{l}-0.0063 \\
{[0.004]}\end{array}$ & $\begin{array}{l}-0.0035 \\
{[0.004]}\end{array}$ \\
\hline Tier2 capital & & & & & $\begin{array}{l}0.0070 \\
{[0.027]}\end{array}$ & $\begin{array}{l}-0.0283 \\
{[0.045]}\end{array}$ & $\begin{array}{l}-0.0178 \\
{[0.045]}\end{array}$ \\
\hline Leverage ratio & & & & & & $\begin{array}{l}0.0357^{* *} \\
{[0.015]}\end{array}$ & $\begin{array}{l}0.0462^{* * * *} \\
{[0.016]}\end{array}$ \\
\hline Economic risk rating & & & & & & & $\begin{array}{l}0.0222 \\
{[0.029]}\end{array}$ \\
\hline Financial risk rating & & & & & & & $\begin{array}{l}-0.0362^{*} \\
{[0.020]}\end{array}$ \\
\hline Political risk rating & & & & & & & $\begin{array}{l}-0.0397^{\text {*** }} \\
{[0.015]}\end{array}$ \\
\hline Constant & $\begin{array}{l}2.9747^{* * *} \\
{[0.267]}\end{array}$ & $\begin{array}{l}3.6069^{* * *} \\
{[0.346]}\end{array}$ & $\begin{array}{l}3.6051^{* * *} \\
{[0.346]}\end{array}$ & $\begin{array}{l}3.9717^{* * *} \\
{[0.365]}\end{array}$ & $\begin{array}{l}4.0932^{* * *} \\
{[0.405]}\end{array}$ & $\begin{array}{l}3.9152^{* * * *} \\
{[0.472]}\end{array}$ & $\begin{array}{l}7.4479^{* * * *} \\
{[1.745]}\end{array}$ \\
\hline Observations & 326 & 262 & 262 & 255 & 234 & 130 & 130 \\
\hline R-squared & 0.708 & 0.721 & 0.722 & 0.736 & 0.730 & 0.795 & 0.807 \\
\hline
\end{tabular}

Notes: Standard errors in brackets.

${ }^{* * *} \mathrm{p}<0.01$.

** $\mathrm{p}<0.05$.

* $\mathrm{p}<0.1$.

Table 2

Determinants of the bank CDS spreads - RE.

\begin{tabular}{|c|c|c|c|c|c|c|c|}
\hline Variables & (1) & $(2)$ & (3) & (4) & (5) & (6) & (7) \\
\hline House price & $\begin{array}{l}-0.0257 \\
{[0.071]}\end{array}$ & $\begin{array}{l}-0.1714^{*} \\
{[0.096]}\end{array}$ & $\begin{array}{l}-0.1615^{*} \\
{[0.097]}\end{array}$ & $\begin{array}{l}-0.1968^{* *} \\
{[0.093]}\end{array}$ & $\begin{array}{l}-0.2180^{* *} \\
{[0.105]}\end{array}$ & $\begin{array}{l}-0.2117^{* *} \\
{[0.107]}\end{array}$ & $\begin{array}{l}-0.2000^{* *} \\
{[0.100]}\end{array}$ \\
\hline Asset quality & & $\begin{array}{l}0.0046^{* * *} \\
{[0.001]}\end{array}$ & $\begin{array}{l}0.0043^{* * * *} \\
{[0.001]}\end{array}$ & $\begin{array}{l}0.0043^{* * * *} \\
{[0.001]}\end{array}$ & $\begin{array}{l}0.0047^{* * *} \\
{[0.001]}\end{array}$ & $\begin{array}{l}0.0078^{* * * * *} \\
{[0.003]}\end{array}$ & $\begin{array}{l}0.0075^{* * * *} \\
{[0.003]}\end{array}$ \\
\hline Operations income ratio & & & $\begin{array}{l}-0.0586 \\
{[0.044]}\end{array}$ & $\begin{array}{l}-0.0459 \\
{[0.042]}\end{array}$ & $\begin{array}{l}-0.0641 \\
{[0.044]}\end{array}$ & $\begin{array}{l}0.0137 \\
{[0.059]}\end{array}$ & $\begin{array}{l}0.0007 \\
{[0.062]}\end{array}$ \\
\hline Liquidity ratio & & & & $\begin{array}{l}-0.0104^{* * *} \\
{[0.004]}\end{array}$ & $\begin{array}{l}-0.0126^{*} \\
{[0.005]}\end{array}$ & $\begin{array}{l}-0.0097^{*} \\
{[0.005]}\end{array}$ & $\begin{array}{l}-0.0065 \\
{[0.005]}\end{array}$ \\
\hline Tier2 capital & & & & & $\begin{array}{l}-0.0355 \\
{[0.029]}\end{array}$ & $\begin{array}{l}-0.0317 \\
{[0.051]}\end{array}$ & $\begin{array}{l}-0.0201 \\
{[0.050]}\end{array}$ \\
\hline Leverage ratio & & & & & & $\begin{array}{l}0.0289^{*} \\
{[0.018]}\end{array}$ & $\begin{array}{l}0.0375^{* *} \\
{[0.017]}\end{array}$ \\
\hline Economic risk rating & & & & & & & $\begin{array}{l}0.0024 \\
{[0.029]}\end{array}$ \\
\hline Financial risk rating & & & & & & & $\begin{array}{l}-0.0239 \\
{[0.021]}\end{array}$ \\
\hline Political risk rating & & & & & & & $\begin{array}{l}-0.0273^{*} \\
{[0.015]}\end{array}$ \\
\hline Constant & $\begin{array}{l}3.0932^{* * *} \\
{[0.371]}\end{array}$ & $\begin{array}{l}3.7660^{* * * *} \\
{[0.502]}\end{array}$ & $\begin{array}{l}3.7950^{* * *} \\
{[0.507]}\end{array}$ & $\begin{array}{l}4.1777^{* * * *} \\
{[0.500]}\end{array}$ & $\begin{array}{l}4.5385^{* * *} \\
{[0.578]}\end{array}$ & $\begin{array}{l}4.2097^{\text {****}} \\
{[0.598]}\end{array}$ & $\begin{array}{l}6.9904^{* * * *} \\
{[1.782]}\end{array}$ \\
\hline Observations & 326 & 262 & 262 & 255 & 234 & 130 & 130 \\
\hline Number of banks & 53 & 51 & 51 & 50 & 48 & 26 & 26 \\
\hline
\end{tabular}

Notes: Standard errors in brackets.

*** $\mathrm{p}<0.01$.

** $p<0.05$.

* $\mathrm{p}<0.1$.

Finally, risk ratings appear to affect bank CDS spreads in a significant manner. In particular, an improvement in the political risk rating is associated with a statistically significant reduction of bank CDS spreads. There is also some evidence, albeit weak, that better financial risk ratings reduce bank CDS spreads, but the effect is not consistently significant across the three econometric methodologies. 
Table 3

Determinants of the bank CDS spreads - FE.

\begin{tabular}{|c|c|c|c|c|c|c|c|}
\hline Variables & $(1)$ & $(2)$ & (3) & $(4)$ & (5) & (6) & $(7)$ \\
\hline House price & $\begin{array}{l}-0.9258 \\
{[0.588]}\end{array}$ & $\begin{array}{l}-1.5770^{* *} \\
{[0.710]}\end{array}$ & $\begin{array}{l}-1.2654^{*} \\
{[0.723]}\end{array}$ & $\begin{array}{l}-1.3042^{*} \\
{[0.716]}\end{array}$ & $\begin{array}{l}-0.5007 \\
{[0.815]}\end{array}$ & $\begin{array}{l}-0.0554 \\
{[0.973]}\end{array}$ & $\begin{array}{l}0.0791 \\
{[1.020]}\end{array}$ \\
\hline Asset quality & & $\begin{array}{l}0.0048^{* * * *} \\
{[0.002]}\end{array}$ & $\begin{array}{l}0.0051^{* * * *} \\
{[0.002]}\end{array}$ & $\begin{array}{l}0.0056^{* * * *} \\
{[0.002]}\end{array}$ & $\begin{array}{l}0.0067^{* * * *} \\
{[0.002]}\end{array}$ & $\begin{array}{l}0.0187^{* * *} \\
{[0.004]}\end{array}$ & $\begin{array}{l}0.0203^{* * * *} \\
{[0.004]}\end{array}$ \\
\hline Operations income ratio & & & $\begin{array}{l}-0.1129 \\
{[0.058]}\end{array}$ & $\begin{array}{l}-0.1128^{*} \\
{[0.058]}\end{array}$ & $\begin{array}{l}-0.1426^{* *} \\
{[0.060]}\end{array}$ & $\begin{array}{l}-0.2079^{* *} \\
{[0.082]}\end{array}$ & $\begin{array}{l}-0.2100 \\
{[0.082]}\end{array}$ \\
\hline Liquidity ratio & & & & $\begin{array}{l}-0.0076 \\
{[0.006]}\end{array}$ & $\begin{array}{l}-0.0120^{*} \\
{[0.007]}\end{array}$ & $\begin{array}{l}-0.0128 \\
{[0.009]}\end{array}$ & $\begin{array}{l}-0.0110 \\
{[0.010]}\end{array}$ \\
\hline Tier2 capital & & & & & $\begin{array}{l}-0.0653^{* *} \\
{[0.032]}\end{array}$ & $\begin{array}{l}-0.0451 \\
{[0.068]}\end{array}$ & $\begin{array}{l}-0.0771 \\
{[0.072]}\end{array}$ \\
\hline Leverage ratio & & & & & & $\begin{array}{l}0.0109 \\
{[0.025]}\end{array}$ & $\begin{array}{l}0.0048 \\
{[0.025]}\end{array}$ \\
\hline Economic risk rating & & & & & & & $\begin{array}{l}0.0141 \\
{[0.032]}\end{array}$ \\
\hline Financial risk rating & & & & & & & $\begin{array}{l}-0.0031 \\
{[0.030]}\end{array}$ \\
\hline Political risk rating & & & & & & & $\begin{array}{l}0.0363 \\
{[0.026]}\end{array}$ \\
\hline Constant & $\begin{array}{l}7.6033^{* *} \\
{[2.941]}\end{array}$ & $\begin{array}{l}10.6653^{* * *} \\
{[3.499]}\end{array}$ & $\begin{array}{l}9.2557^{* * *} \\
{[3.550]}\end{array}$ & $\begin{array}{l}9.56611^{* * *} \\
{[3.507]}\end{array}$ & $\begin{array}{l}6.0509 \\
{[3.983]}\end{array}$ & $\begin{array}{l}3.4963 \\
{[4.828]}\end{array}$ & $\begin{array}{l}-0.4625 \\
{[5.912]}\end{array}$ \\
\hline Observations & 326 & 262 & 262 & 255 & 234 & 130 & 130 \\
\hline R-squared & 0.796 & 0.809 & 0.813 & 0.818 & 0.817 & 0.844 & 0.848 \\
\hline Number of banks & 53 & 51 & 51 & 50 & 48 & 26 & 26 \\
\hline Hausman test ( $p$-value) & 0.000 & 0.082 & 0.063 & 0.031 & 0.364 & 0.021 & 0.005 \\
\hline
\end{tabular}

Notes: Standard errors in brackets.

**** $\mathrm{p}<0.01$

** $\mathrm{p}<0.05$

$\mathrm{p}<0.1$.

\subsection{Model with financial structure indicators}

In Table 4, we provide a summary of the results from the estimation of our baseline model, i.e. the specification that adds the four financial structure indicators to the set of control variables.

As indicated by the Hausman's (1978) specification test, the FE model outperforms the RE model, thus, we focus on the former. Columns 1-4 report the main findings where we add one financial structure indicator at a time. Thus, in Column 4 , all four indicators are included in the baseline model.

Considering the explanatory variables included in the narrow version of the model, the empirical findings are both quantitatively and qualitatively similar. In fact: (i) house prices tend to be negatively associated with bank CDS spreads; (ii) a deterioration of asset quality is linked with a significant rise in credit risk; (iii) an increase in profitability reduces bank CDS spreads; and (iv) there is some evidence that more liquid assets correlate with lower credit risk. The evidence is somewhat weaker regarding the importance of regulatory capital, the leverage ratio and the risk rating indices, which remain weakly significant in the various model specifications.

Looking at the four indicators of the financial structure, we find that financial stability (as proxied by banks' Z-score) exerts a significant and negative effect on bank CDS spreads. As the banks' Z-score is inversely related with the probability of default of a country's banking system, it can be thought as a buffer that protects it vis-à-vis potential financial crises. Thus, the longer the distance to default, the higher the banks' Z-score and the more stable the financial system is and, the lower the bank CDS spreads are.

Additionally, the results do not seem to point to a statistically significant effect of other financial structure indicators on bank CDS spreads. In particular, neither financial depth (as proxied by the ratio of deposit money bank assets to GDP), nor financial access (as measured by the number of bank branches per 100,000 adults) seem to affect bank CDS spreads in a significant manner in this static model.

In Columns 5 and 6, we take into account that a bank's regulatory capital may reflect the outcome of the country's financial system. For example, a higher regulatory capital for a bank may be due to the high degree of financial stability in the country's system. From an empirical point of view, the two control variables may be collinear. Thus, in Column 5, we remove Tier 2 capital from the set of explanatory variables and, in Column 6, we drop financial stability from the set of control variables.

The findings are both quantitatively and qualitatively very close to those reported in Column 4 (i.e. our baseline model). Thus, while regulatory capital remains insignificant, financial stability is still negatively and significantly associated with 
Table 4

Regulatory structure and financial system - FE.

\begin{tabular}{|c|c|c|c|c|c|c|}
\hline Variables & (1) & (2) & (3) & (4) & (5) & (6) \\
\hline \multirow[t]{2}{*}{ House price } & 0.0684 & 0.2941 & -2.2957 & -2.4843 & $-2.9381^{* * *}$ & -2.0630 \\
\hline & [1.026] & {$[1.060]$} & [1.469] & {$[1.481]$} & [1.438] & [1.548] \\
\hline \multirow[t]{2}{*}{ Asset quality } & $0.0199^{* * * *}$ & $0.0229^{* * *}$ & $0.0314^{* * * *}$ & $0.0315^{* * * *}$ & $0.0227^{* * * *}$ & $0.0330^{* * * *}$ \\
\hline & [0.005] & {$[0.006]$} & {$[0.006]$} & {$[0.006]$} & [0.005] & [0.006] \\
\hline \multirow[t]{2}{*}{ Operations income ratio } & $-0.2060^{* *}$ & $-0.2375^{* *}$ & $-0.3739^{* * *}$ & $-0.3817^{* * *}$ & $-0.2828^{* * *}$ & $-0.4021^{* * *}$ \\
\hline & {$[0.084]$} & [0.091] & {$[0.085]$} & {$[0.085]$} & {$[0.078]$} & [0.089] \\
\hline \multirow[t]{2}{*}{ Liquidity ratio } & -0.0106 & -0.0100 & 0.0037 & 0.0024 & $-0.0178^{*}$ & 0.0002 \\
\hline & {$[0.010]$} & {$[0.010]$} & {$[0.011]$} & [0.011] & [0.009] & {$[0.012]$} \\
\hline \multirow[t]{2}{*}{ Tier2 capital } & -0.0744 & -0.0927 & -0.1088 & -0.0915 & & -0.1256 \\
\hline & {$[0.073]$} & {$[0.076]$} & {$[0.072]$} & {$[0.074]$} & & [0.077] \\
\hline \multirow[t]{2}{*}{ Leverage ratio } & 0.0056 & -0.0046 & -0.0323 & -0.0339 & -0.0008 & -0.0395 \\
\hline & {$[0.025]$} & {$[0.028]$} & {$[0.026]$} & {$[0.026]$} & {$[0.024]$} & {$[0.027]$} \\
\hline \multirow[t]{2}{*}{ Economic risk rating } & 0.0164 & 0.0105 & -0.0633 & -0.0626 & -0.0486 & -0.0635 \\
\hline & [0.033] & {$[0.034]$} & {$[0.040]$} & [0.040] & [0.042] & [0.043] \\
\hline \multirow[t]{2}{*}{ Financial risk rating } & -0.0050 & -0.0115 & 0.0190 & 0.0330 & 0.0054 & 0.0222 \\
\hline & {$[0.031]$} & {$[0.032]$} & {$[0.051]$} & {$[0.053]$} & {$[0.054]$} & {$[0.056]$} \\
\hline \multirow[t]{2}{*}{ Political risk rating } & 0.0361 & 0.0262 & 0.0027 & -0.0044 & -0.0375 & -0.0023 \\
\hline & {$[0.026]$} & {$[0.028]$} & {$[0.038]$} & {$[0.038]$} & [0.037] & {$[0.040]$} \\
\hline \multirow[t]{2}{*}{ Financial stability } & -0.0075 & -0.0112 & $-0.0618^{* *}$ & $-0.0646^{* *}$ & $-0.0771^{* * * *}$ & \\
\hline & {$[0.025]$} & {$[0.025]$} & {$[0.027]$} & {$[0.027]$} & {$[0.028]$} & \\
\hline \multirow[t]{2}{*}{ Financial depth } & & -0.0059 & $-0.0172^{*}$ & -0.0142 & -0.0075 & -0.0140 \\
\hline & & {$[0.007]$} & [0.009] & {$[0.009]$} & {$[0.009]$} & {$[0.010]$} \\
\hline \multirow[t]{2}{*}{ Financial access } & & & -0.0072 & -0.0087 & -0.0030 & -0.0064 \\
\hline & & & {$[0.015]$} & {$[0.015]$} & {$[0.015]$} & {$[0.016]$} \\
\hline \multirow[t]{2}{*}{ Financial efficiency } & & & & 0.2060 & $0.3812^{* * *}$ & 0.1544 \\
\hline & & & & {$[0.207]$} & {$[0.174]$} & {$[0.216]$} \\
\hline \multirow[t]{2}{*}{ Constant } & -0.2981 & 0.5402 & $18.5364^{* * *}$ & $19.0326^{* * *}$ & $23.9867^{* *}$ & $16.2794^{*}$ \\
\hline & [5.968] & [6.054] & {$[8.968]$} & {$[8.982]$} & {$[9.242]$} & [9.377] \\
\hline Observations & 130 & 130 & 83 & 83 & 89 & 83 \\
\hline R-squared & 0.849 & 0.850 & 0.929 & 0.931 & 0.922 & 0.922 \\
\hline Number of id & 26 & 26 & 21 & 21 & 21 & 21 \\
\hline Hausman test ( $p$-value) & 0.012 & 0.017 & 0.049 & 0.054 & 0.044 & 0.089 \\
\hline
\end{tabular}

Notes: Standard errors in brackets.

*** $\mathrm{p}<0.01$.

*** $\mathrm{p}<0.05$.

$\mathrm{p}<0.1$.

bank CDS spreads. Interestingly, in the specification where we exclude regulatory capital (i.e. Column 5), financial efficiency (which is proxied by overhead costs to total assets) becomes statistically significant. This suggests that the variation in bank CDS spreads can capture changes in financial system efficiency.

\subsection{A GMM approach}

We also consider a dynamic panel specification by adding lagged bank CDS spreads to the set of control variables and estimating the model with the Generalized Method of Moments (GMM) approach. Table 5 provides a summary of the results. The empirical findings are consistent with those found in previous sections. Thus, some bank-level characteristics are key determinants of bank CDS spreads. In particular, (i) an improvement in banks' asset quality, (ii) a rise in banks' profitability and (iii) an increase in the liquidity of the assets held by banks is associated with lower credit risk.

Additionally, the structure of financial system of the country plays a role. More specifically, greater financial stability tends to correlate negatively with bank CDS spreads, while more financial depth appears to correlate positively with them.

Finally, we highlight that the lagged bank CDS spread enters significantly in the GMM regressions, which corroborates the idea that the dynamic panel is a better description of the dynamics of credit risk than the static panel. Moreover, the Arellano and Bond (1991) test shows that there is no second-order autocorrelation and the Sargan-Hansen test confirms the validity of the instruments.

As shown in Table 6 (in column 2), the coefficient on financial depth reflecting the size of the banking sector suggests that countries with smaller banking sectors may display lower credit risk and narrower CDS spread. This relationship is also in accordance with the idea that the easy credit provision to low-income consumers partly contributed to an increase in the level of credit risk. But this might have been offset by a corresponding appreciation in house price. Thus in Table 6 (in column $6)$, we present the results without financial depth which appears to corroborate this view. 
Table 5

GMM estimation results.

\begin{tabular}{|c|c|c|c|c|}
\hline Variables & (1) & $(2)$ & (3) & (4) \\
\hline Lagged bank CDS spreads & $\begin{array}{l}0.2114^{* * *} \\
{[0.081]}\end{array}$ & $\begin{array}{l}0.1251^{*} \\
{[0.074]}\end{array}$ & $\begin{array}{l}0.1336 \\
{[0.135]}\end{array}$ & $\begin{array}{l}0.1653 \\
{[0.136]}\end{array}$ \\
\hline House price & $\begin{array}{l}-0.3779 \\
{[0.324]}\end{array}$ & $\begin{array}{l}-0.2374 \\
{[0.337]}\end{array}$ & $\begin{array}{l}-1.2398^{* *} \\
{[0.547]}\end{array}$ & $\begin{array}{l}-1.0777^{*} \\
{[0.597]}\end{array}$ \\
\hline Asset quality & $\begin{array}{l}0.0132^{* * *} \\
{[0.003]}\end{array}$ & $\begin{array}{l}0.0109^{* * *} \\
{[0.003]}\end{array}$ & $\begin{array}{l}0.0265^{* * *} \\
{[0.009]}\end{array}$ & $\begin{array}{l}0.0194^{* * *} \\
{[0.005]}\end{array}$ \\
\hline Operations income ratio & $\begin{array}{l}-0.1897^{* *} \\
{[0.076]}\end{array}$ & $\begin{array}{l}-0.1588^{* * *} \\
{[0.052]}\end{array}$ & $\begin{array}{l}-0.4187^{* *} \\
{[0.178]}\end{array}$ & $\begin{array}{l}-0.3112 \\
{[0.056]}\end{array}$ \\
\hline Liquidity ratio & $\begin{array}{l}-0.0652^{* * * *} \\
{[0.008]}\end{array}$ & $\begin{array}{l}-0.0528^{* * *} \\
{[0.009]}\end{array}$ & $\begin{array}{l}-0.0655^{* * *} \\
{[0.015]}\end{array}$ & $\begin{array}{l}-0.0655^{* * *} \\
{[0.013]}\end{array}$ \\
\hline Tier2 capital & $\begin{array}{l}-0.0895 \\
{[0.092]}\end{array}$ & $\begin{array}{l}-0.0964 \\
{[0.084]}\end{array}$ & $\begin{array}{l}-0.0523 \\
{[0.070]}\end{array}$ & $\begin{array}{l}-0.0902 \\
{[0.122]}\end{array}$ \\
\hline Leverage ratio & $\begin{array}{l}-0.0001 \\
{[0.021]}\end{array}$ & $\begin{array}{l}0.0064 \\
{[0.021]}\end{array}$ & $\begin{array}{l}-0.0154 \\
{[0.039]}\end{array}$ & $\begin{array}{l}0.0136 \\
{[0.025]}\end{array}$ \\
\hline Economic risk rating & $\begin{array}{l}-0.0497^{* * *} \\
{[0.018]}\end{array}$ & $\begin{array}{l}-0.0233 \\
{[0.018]}\end{array}$ & $\begin{array}{l}-0.0262 \\
{[0.026]}\end{array}$ & $\begin{array}{l}-0.0064 \\
{[0.026]}\end{array}$ \\
\hline Financial risk rating & $\begin{array}{l}-0.0685^{* * *} \\
{[0.018]}\end{array}$ & $\begin{array}{l}-0.0174 \\
{[0.016]}\end{array}$ & $\begin{array}{l}-0.0530^{*} \\
{[0.031]}\end{array}$ & $\begin{array}{l}0.0059 \\
{[0.040]}\end{array}$ \\
\hline Political risk rating & $\begin{array}{l}-0.0394 \\
{[0.032]}\end{array}$ & $\begin{array}{l}-0.0106 \\
{[0.025]}\end{array}$ & $\begin{array}{l}-0.0498 \\
{[0.044]}\end{array}$ & $\begin{array}{l}-0.0583 \\
{[0.040]}\end{array}$ \\
\hline Financial stability & $\begin{array}{l}-0.0114 \\
{[0.026]}\end{array}$ & $\begin{array}{l}-0.0030 \\
{[0.028]}\end{array}$ & $\begin{array}{l}-0.0460 \\
{[0.037]}\end{array}$ & $\begin{array}{l}-0.0776^{*} \\
{[0.041]}\end{array}$ \\
\hline Financial depth & & $\begin{array}{l}0.0217^{* * *} \\
{[0.006]}\end{array}$ & $\begin{array}{l}0.0139 \\
{[0.013]}\end{array}$ & $\begin{array}{l}0.0288^{*} \\
{[0.017]}\end{array}$ \\
\hline Financial access & & & $\begin{array}{l}0.0029 \\
{[0.014]}\end{array}$ & $\begin{array}{l}-0.0023 \\
{[0.016]}\end{array}$ \\
\hline Financial efficiency & & & & $\begin{array}{l}0.9893^{*} \\
{[0.540]}\end{array}$ \\
\hline Constant & $\begin{array}{l}14.5712^{* * *} \\
{[3.630]}\end{array}$ & $\begin{array}{l}5.9372^{* *} \\
{[3.000]}\end{array}$ & $\begin{array}{l}16.6958^{* * *} \\
{[6.232]}\end{array}$ & $\begin{array}{l}11.1220^{* *} \\
{[4.814]}\end{array}$ \\
\hline Observations & 121 & 121 & 78 & 78 \\
\hline Number of banks & 26 & 26 & 21 & 21 \\
\hline Number of instruments & 24 & 25 & 26 & 27 \\
\hline ar1 ( $p$-value) & 0.013 & 0.013 & 0.056 & 0.074 \\
\hline ar2 ( $p$-value) & 0.840 & 0.718 & 0.143 & 0.413 \\
\hline Sargan test ( $p$-value) & 0.132 & 0.088 & 0.688 & 0.768 \\
\hline
\end{tabular}

Notes: Standard errors in brackets.

${ }^{* * *} \mathrm{p}<0.01$.

*** $\mathrm{p}<0.05$.

$\mathrm{p}<0.1$.

Table 6

GMM estimation using house price and financial depth alternatively.

\begin{tabular}{|c|c|c|c|c|c|c|}
\hline Variables & (1) & (2) & (3) & (4) & (5) & (6) \\
\hline Lagged bank CDS spreads & $\begin{array}{l}0.2114^{* * *} \\
{[0.081]}\end{array}$ & $\begin{array}{l}0.1251 \\
{[0.074]}\end{array}$ & $\begin{array}{l}0.1336 \\
{[0.135]}\end{array}$ & $\begin{array}{l}0.1653 \\
{[0.136]}\end{array}$ & $\begin{array}{l}-0.0199 \\
{[0.084]}\end{array}$ & $\begin{array}{l}0.2694 \\
{[0.125]}\end{array}$ \\
\hline House price & $\begin{array}{l}-0.3779 \\
{[0.324]}\end{array}$ & $\begin{array}{l}-0.2374 \\
{[0.337]}\end{array}$ & $\begin{array}{l}-1.2398^{* *} \\
{[0.547]}\end{array}$ & $\begin{array}{l}-1.0777^{*} \\
{[0.597]}\end{array}$ & & $\begin{array}{l}-1.6258 \\
{[0.493]}\end{array}$ \\
\hline Asset quality & $\begin{array}{l}0.0132^{* * *} \\
{[0.003]}\end{array}$ & $\begin{array}{l}0.0109 \\
{[0.003]}\end{array}$ & $\begin{array}{l}0.0265^{* * *} \\
{[0.009]}\end{array}$ & $\begin{array}{l}0.0194^{* * *} \\
{[0.005]}\end{array}$ & $\begin{array}{l}0.0264^{* * *} \\
{[0.005]}\end{array}$ & $\begin{array}{l}0.0285^{* * *} \\
{[0.006]}\end{array}$ \\
\hline Operations income ratio & $\begin{array}{l}-0.1897^{* *} \\
{[0.076]}\end{array}$ & $\begin{array}{l}-0.1588 \\
{[0.052]}\end{array}$ & $\begin{array}{l}-0.4187^{* *} \\
{[0.178]}\end{array}$ & $\begin{array}{l}-0.3112^{* * *} \\
{[0.056]}\end{array}$ & $\begin{array}{l}-0.3656^{* * *} \\
{[0.060]}\end{array}$ & $\begin{array}{l}-0.4775 \\
{[0.073]}\end{array}$ \\
\hline Liquidity ratio & $\begin{array}{l}-0.0652^{* * *} \\
{[0.008]}\end{array}$ & $\begin{array}{l}-0.0528 \\
{[0.009]}\end{array}$ & $\begin{array}{l}-0.0655^{* * *} \\
{[0.015]}\end{array}$ & $\begin{array}{l}-0.0655^{* * *} \\
{[0.013]}\end{array}$ & $\begin{array}{l}-0.0736^{* * *} \\
{[0.013]}\end{array}$ & $\begin{array}{l}-0.0600 \\
{[0.013]}\end{array}$ \\
\hline Tier2 capital & $\begin{array}{l}-0.0895 \\
{[0.092]}\end{array}$ & $\begin{array}{l}-0.0964 \\
{[0.084]}\end{array}$ & $\begin{array}{l}-0.0523 \\
{[0.070]}\end{array}$ & $\begin{array}{l}-0.0902 \\
{[0.122]}\end{array}$ & $\begin{array}{l}-0.0928^{* *} \\
{[0.046]}\end{array}$ & $\begin{array}{l}0.0268 \\
{[0.115]}\end{array}$ \\
\hline Leverage ratio & $\begin{array}{l}-0.0001 \\
{[0.021]}\end{array}$ & $\begin{array}{l}0.0064 \\
{[0.021]}\end{array}$ & $\begin{array}{l}-0.0154 \\
{[0.039]}\end{array}$ & $\begin{array}{l}0.0136 \\
{[0.025]}\end{array}$ & $\begin{array}{l}-0.0176 \\
{[0.026]}\end{array}$ & $\begin{array}{l}-0.0158 \\
{[0.030]}\end{array}$ \\
\hline Economic risk rating & $\begin{array}{l}-0.0497^{* * *} \\
{[0.018]}\end{array}$ & $\begin{array}{l}-0.0233 \\
{[0.018]}\end{array}$ & $\begin{array}{l}-0.0262 \\
{[0.026]}\end{array}$ & $\begin{array}{l}-0.0064 \\
{[0.026]}\end{array}$ & $\begin{array}{l}-0.0634^{* * *} \\
{[0.013]}\end{array}$ & $\begin{array}{l}-0.0280 \\
{[0.028]}\end{array}$ \\
\hline Financial risk rating & $\begin{array}{l}-0.0685^{* * *} \\
{[0.018]}\end{array}$ & $\begin{array}{l}-0.0174 \\
{[0.016]}\end{array}$ & $\begin{array}{l}-0.0530^{*} \\
{[0.031]}\end{array}$ & $\begin{array}{l}0.0059 \\
{[0.040]}\end{array}$ & $\begin{array}{l}-0.0802^{* * *} \\
{[0.022]}\end{array}$ & $\begin{array}{l}-0.0237 \\
{[0.030]}\end{array}$ \\
\hline
\end{tabular}


Table 6 (continued)

\begin{tabular}{|c|c|c|c|c|c|c|}
\hline Variables & (1) & (2) & (3) & (4) & (5) & (6) \\
\hline Political risk rating & $\begin{array}{l}-0.0394 \\
{[0.032]}\end{array}$ & $\begin{array}{l}-0.0106 \\
{[0.025]}\end{array}$ & $\begin{array}{l}-0.0498 \\
{[0.044]}\end{array}$ & $\begin{array}{l}-0.0583 \\
{[0.040]}\end{array}$ & $\begin{array}{l}-0.0834^{* * *} \\
{[0.027]}\end{array}$ & $\begin{array}{l}-0.0939^{* *} \\
{[0.046]}\end{array}$ \\
\hline Financial stability & $\begin{array}{l}-0.0114 \\
{[0.026]}\end{array}$ & $\begin{array}{l}-0.0030 \\
{[0.028]}\end{array}$ & $\begin{array}{l}-0.0460 \\
{[0.037]}\end{array}$ & $\begin{array}{l}-0.0776^{*} \\
{[0.041]}\end{array}$ & $\begin{array}{l}-0.0070 \\
{[0.023]}\end{array}$ & $\begin{array}{l}-0.0737^{*} \\
{[0.042]}\end{array}$ \\
\hline Financial depth & & $\begin{array}{l}0.0217 \\
{[0.006]}\end{array}$ & $\begin{array}{l}0.0139 \\
{[0.013]}\end{array}$ & $\begin{array}{l}0.0288^{*} \\
{[0.017]}\end{array}$ & $\begin{array}{l}0.0130 \\
{[0.009]}\end{array}$ & \\
\hline Financial access & & & $\begin{array}{l}0.0029 \\
{[0.014]}\end{array}$ & $\begin{array}{l}-0.0023 \\
{[0.016]}\end{array}$ & $\begin{array}{l}0.0032 \\
{[0.014]}\end{array}$ & $\begin{array}{l}0.0278 \\
{[0.010]}\end{array}$ \\
\hline Financial efficiency & & & & $\begin{array}{l}0.9893^{*} \\
{[0.540]}\end{array}$ & $\begin{array}{l}0.0710 \\
{[0.109]}\end{array}$ & $\begin{array}{l}0.3068 \\
{[0.354]}\end{array}$ \\
\hline Constant & $\begin{array}{l}14.5712^{* * * *} \\
{[3.630]}\end{array}$ & $\begin{array}{l}5.9372 \\
{[3.000]}\end{array}$ & $\begin{array}{l}16.6958^{* * *} \\
{[6.232]}\end{array}$ & $\begin{array}{l}11.1220^{* *} \\
{[4.814]}\end{array}$ & $\begin{array}{l}15.6506^{* * *} \\
{[2.382]}\end{array}$ & $\begin{array}{l}20.7841 \\
{[4.405]}\end{array}$ \\
\hline Observations & 121 & 121 & 78 & 78 & 94 & 78 \\
\hline Number of banks & 26 & 26 & 21 & 21 & 24 & 21 \\
\hline Number of instruments & 24 & 25 & 26 & 27 & 26 & 26 \\
\hline ar1 ( $p$-value) & 0.013 & 0.013 & 0.056 & 0.074 & 0.067 & 0.106 \\
\hline ar2 ( $p$-value) & 0.840 & 0.718 & 0.143 & 0.413 & 0.726 & 0.244 \\
\hline Sargan test ( $p$-value) & 0.132 & 0.088 & 0.688 & 0.768 & 0.494 & 0.878 \\
\hline
\end{tabular}

Notes: Standard errors in brackets.

*** $\mathrm{p}<0.01$.

** $p<0.05$.

$\mathrm{p}<0.1$.

\section{Conclusion}

The global financial turmoil of 2008-2009 was a witness of the need to identify the drivers of the bank CDS spreads as indicators of credit risk, to ensure the stability of the financial system as a whole. In this context, the current paper investigates both bank-level and country-level drivers of the bank CDS spreads using annual data for 58 banks from 15 countries over the period of 2004-2011.

We show that, among bank-level characteristics, asset quality, liquidity and profitability play a major role. In particular, banks with stronger liquidity levels tend to display less credit risk. Similarly, banks with better asset quality are more likely to observe lower default probabilities. And higher profitability is associated with lower credit risk.

Country-level financial structure is also a key driver of bank CDS spreads. More specifically, countries with more financial stability seem less prone to episodes of heightened credit risk. However, country-level access to financial services does not seem to significantly impact on bank CDS spreads.

In light of the damaging consequences of the Great Recession and from a policy perspective, our work shows that understanding the key drivers of credit risk is essential to ensure a sound functioning of the financial system. More specifically, a vigilant track of the asset quality and the profitability of banks can prove particularly useful for assessing the dynamics of credit risk. Similarly, the Z-score (i.e. a proxy for the stability of the financial system as a whole) provides extremely relevant information about the variation in credit risk.

\section{References}

Alexander, C., Kaeck, A., 2008. Regime dependent determinants of credit default swap spreads. J. Bank. Financ. 32 (6), $1008-1021$

Ambrose, B., LaCour-Little, M., Sanders, A., 2005. Does regulatory capital arbitrage or asymmetric information drive securitization? J. Financ. Serv. Res. 28, $113-133$.

Annaert, J., De Ceuster, M., Van Roy, P., Vespro, C., 2013. What determines Euro area bank CDS spreads? J. Int. Money Financ. 32, $444-461$.

Arellano, M., Bond, S., 1991. Some tests of specification for panel data: Monte Carlo evidence and an application to employment equations. Rev. Econ. Stud. $58,277-297$.

Benbouzid, N., Mallick, S.K., 2013. Determinants of bank credit default swap spreads: the role of the housing sector. N. Am. J. Econ. Financ. 24 (1), $243-259$. Benkert, C., 2004. Explaining credit default swap premia. J. Futures Mark. 24 (1), 71-92.

Bernanke, B., Gertler, M., 1999. Monetary policy and asset price volatility. Fed. Reserve Bank Kansas City Proc., 77-128

Beck, T., Demirgüç-Kunt, A., Martinez Peria, M.S., 2007. Reaching out: access to and use of banking services across countries. J. Financ. Econ. 85 (1), 234-266.

Beck, T., Demirgüç-Kunt, A., Martinez Peria, M.S., 2008. Banking services for everyone? Barriers to bank access and use around the world. World Bank Econ. Rev. 22 (3), 397-430.

Blanco, R., Brennan, S., Marsh, I.W., 2005. An empirical analysis of the dynamic relation between investment-grade bonds and credit default swaps. J. Financ. 60 (5), 2255-2281.

Campbell, J.T., Taksler, G.B., 2003. Equity volatility and corporate bond yields. J. Financ. 58, 2321-2349.

Chan-Lau, J.A., Gravelle, T., 2005. The end: a new indicator of financial and nonfinancial corporate sector vulnerability. IMF Working Paper No. 05/231.

Chen, L., Lesmond, D.A., Wei, J., 2007. Corporate yield spreads and bond liquidity. J. Financ. 62 (1), 119-149.

Chiaramonte, L., Casu, B., 2013. The determinants of bank CDS spreads: evidence from the financial crisis. Eur. J. Financ. 19 (9), $861-887$.

Cont, R., 2010. Credit default swaps and financial stability. Banque France Financ. Stab. Rev. 14, 35-43.

Collin-Dufresne, P., Goldstein, R.S., Martin, J.S., 2001. The determinants of credit spread changes. J. Financ. 56 (6), $2177-2207$.

Corò, F., Dufour, A., Varotto, S., 2013. Credit and liquidity components of corporate CDS spreads. J. Bank. Financ. 37, 5511-5525.

Diamond, D.W., Rajan, R.G., 2000. A theory of bank capital. J. Financ. 55 (6), 2431-2465. 
Diamond, D.W., Rajan, R.G., 2005. Liquidity shortages and banking crises. J. Financ. 60 (2), 615-647.

Duffie, D., Singleton, K., 1999. Modelling term structures of defaultable bonds. Rev. Financ. Stud. 12 (4), 687-720.

Ericsson, J., Jacobs, K., Oviedo, R., 2009. The determinants of credit default swap premia. J. Financ. Quant. Anal. 44, 109-132.

Fabozzi, F.J., Cheng, X., Chen, R.R., 2007. Exploring the component of credit risk in credit default swaps. Financ. Res. Lett. 4, 10-18.

Galil, K., Shapir, O.M., Amiram, D., Ben-Zion, U., 2014. The determinants of CDS spreads. J. Bank. Financ. 41 (C), $271-282$.

Hasan, I., Liu, L., Zhang, G., 2014. The determinants of global bank credit-default-swap spreads. Bank of Finland Research, Discussion Paper No. 33. Hausman, J.A., 1978. Specification tests in econometrics. Econometrica 46, 1251-1271.

Houweling, P., Vorst, T., 2005. Pricing default swaps: empirical evidence. J. Int. Money Financ. 24 (8), 1200-1225.

Hull, J., Predescu, C., White, M.A., 2004. The relationship between credit default swap spread spreads, bond yields, and credit rating announcements. J. Bank. Financ. 28, 2789-2811.

Huang, X., Zhou, H., Zhu, H., 2009. A framework for assessing the systemic risk of major financial institutions. J. Bank. Financ. 33, 2036-2049.

In, F., Brown, R., Fang, V., 2003. Modelling volatility and changes in the swap spread. Int. Rev. Financ. Anal. 12 (5), 545-561.

International Swaps and Derivatives Association (ISDA), 2008. Annual Report. New York.

Jordà, O., Schularick, M., Taylor, A.M., 2011. Financial crises, credit booms, and external imbalances: 140 years of lessons. IMF Econ. Rev. 59 (2), $340-378$.

Judson, R.A., Owen, A.L., 1999. Estimating dynamic panel data models: a guide for macroeconomists. Econ. Lett. 65, 9-15.

Kick, T., Koetter, M., 2007. Slippery slopes of stress: ordered failure events in German banking. J. Financ. Stab. 3, $132-148$.

Kiviet, J.F., 1995. On bias, inconsistency and efficiency of various estimators in dynamic panel data models. J. Economet. 68, 53-78.

Kretzschmar, G., McNeil, A.J., Kirchner, A., 2010. Integrated models of capital adequacy - why banks are undercapitalised. J. Bank. Financ. 34, 2838-2850.

Lekkos, I., Milas, C., 2001. Identifying the factors that affect interest-rate swap spreads: some evidence from the United States and the United Kingdom. J. Futures Mark. 21, 737-768.

Levine, R., 2005. Finance and growth: theory and evidence. In: Aghion, P., Durlauf, S. (Eds.), Handbook of Economic Growth, vol. 1. Elsevier, pp. 865-934 (Chapter 12).

Longstaff, F.A., Mithal, S., Neis, E., 2005. Default risk or liquidity? New evidence from the credit default swap market. J. Financ. 60 (5), 2212-2253. Markose,

S., Giansante, S., Shaghaghi, A.R., 2012. Too interconnected to fail' financial network of US CDS market: topological fragility and systemic risk. Management 83 (3), 627-646.

Milcheva, S., 2013. A bank lending channel or a credit supply shock? J. Macroecon. 37, 314-332.

Myers, S., Rajan, R., 1998. The paradox of liquidity. Quart. J. Econ. 113, 733-771.

Naifar, N., 2010. What explains default risk premium during the financial crisis? Evidence from Japan. J. Econ. Bus. 63 (5), $412-430$.

Nijskens, R., Wagner, W., 2011. Credit risk transfer activities and systemic risk: how banks became less risky individually but posed greater risks to the financial system at the same time. J. Bank. Financ. 35, 1391-1398.

Obstfeld, M., 2010. The immoderate world economy. J. Int. Money Financ. 29, 603-614.

Ötker-Robe, I., Podpiera, J., 2010. The fundamental determinants of credit default risk for European large complex financial institutions. International Monetary Fund, IMF Working Paper No. 10.

Poghosyan, T., Cihak, M., 2009. Distress in European banks: an analysis based on a new data set. International Monetary Fund, IMF Working Paper No. 9. Rodríguez-Moreno, M., Peña, J.I., 2013. Systemic risk measures: the simpler the better? J. Bank. Financ. 37, 1817-1831.

Roesch, D., Scheule, H., 2012. Capital incentives and adequacy for securitizations. J. Bank. Financ. 36 (3), $733-748$.

Rossignolo, A.F., Fethi, D.M., Shaban, M., 2013. Market crises and Basel capital requirements: could Basel III have been different? Evidence from Portugal, Ireland, Greece and Spain (PIGS). J. Bank. Financ. 37, 1323-1339.

Tang, D.Y., Yan, H., 2007. Liquidity and credit default swap spread. Bank of Canada, Working Paper.

Taylor, J.B., 2009. Getting off Track. Hoover Institution Press, Stanford.

Tian, S., Yang, Y., Zhang, G., 2013. Bank capital, interbank contagion, and bailout policy. J. Bank. Financ. 37 (8), $2765-2778$.

Zhu, H., 2006. An empirical comparison of credit spreads between the bond market and the credit default swap market. J. Financ. Serv. Res. 29 , 211-235. 